\title{
Sea-land total ozone differences from TOMS: GHOST effect
}

\author{
E. Cuevas, ${ }^{1}$ M. Gil, ${ }^{2}$ J. Rodríguez, ${ }^{1}$ M. Navarro, ${ }^{2}$ and K. P. Hoinka ${ }^{3}$
}

\begin{abstract}
Mean global TOMS (Total Ozone Mapping Spectrometer) ozone data, averaged in time, reveals persistent year-to-year differences in total ozone between continents and oceans. This feature has been named GHOST (global hidden ozone structures from TOMS). During Northern Hemisphere summer it can be seen within the latitudinal belt between $40^{\circ} \mathrm{S}$ and $50^{\circ} \mathrm{N}$. The most pronounced land-sea difference in total ozone with values of up to 18 Dobson units is observed between latitudes $35^{\circ} \mathrm{N}$ and $40^{\circ} \mathrm{N}$. The gradients associated with the coastlines are stronger in summer, when transient planetary wave activity decreases, but is still observable in the winter period. The Iberian Peninsula has been selected as a case study to examine the effect of each possible contribution quantitatively. It has been found that the truncation of the lower tropospheric column due to the topography explains $26 \%$ of the landsea differences, while permanent differences in tropopause height distribution can account for a further $8 \%$. After these "corrections" other structures remain. Additional contributions due to the TOMS total ozone retrieval algorithm artifact (absorbing aerosol distribution) are also explored. After considering the optical depths and absorbance of aerosols above the Iberian Peninsula, the remaining $66 \%$ is compatible with the presence of UV-absorbing aerosols whose effects may not be correctly accounted for in the TOMS retrieval algorithm.
\end{abstract}

\section{Introduction}

Evidence of lower total ozone over the continents as compared with their coasts was first reported some decades ago [e.g., Kulkarni et al., 1960]. Although there was great interest at that time in this effect, these studies were thought to be of limited credibility because few observation stations were available. Later, Khrgian [1967] showed that in summer, ozone differences can be up to 9 Dobson units (DU or $\mathrm{m}$ atm $\mathrm{cm}$ ) between coastal and continental stations at the same latitude. He termed these features "continental effect."

The Total Ozone Mapping Spectrometer (TOMS) provides the longest, most complete, and most accurate satellite record of available ozone column data. It has been extensively used to describe the present state of stratospheric ozone [Bojkov et al., 1988; Stolarski et al., 1992; Harris et al., 1997]. Using these data, Danilov et al. [1995] calculated persistent differences between mountains and the surrounding flatlands above the Andes, the Tibetan Plateau, and the Pyrenees. Starovatov and Zheleznyakova [1995] showed a minimum of total ozone content above the high Pamir Mountains in central Asia. Low tropospheric ozone over high mountain ranges such as the Himalayan and the Rocky Mountains was observed by Fishman et al. [1990] by subtracting SAGEderived (Stratospheric Aerosol and Gas Experiment) stratospheric ozone from TOMS total ozone. The relationship

\footnotetext{
'Observatorio Atmosférico de Izaña, Instituto Nacional de Meteorología, Santa Cruz de Tenerife, Spain.

${ }^{2}$ LATMOS, Departamento de Observación de la Tierra, Teledetección y Atmósfera, Instituto Nacional de Técnica Aeroespacial, Madrid, Spain.

${ }^{3}$ Institut für Physik der Atmosphäre, Deutsches Zentrum für Luftund Raumfahrt, Oberpfaffenhofen, Germany.
}

Copyright 2001 by the American Geophysical Union.

Paper number 2001JD900246.

0148-0227/01/2001JD900246\$09.00 between total ozone and topography height was also discussed by Kazimirovsky and Danilov [1997]. On a global scale the mean ozone field shows significant mesoscale gradients across coastlines and across orographic slopes. These gradients in ozone will hereinafter be referred to as the GHOST (global hidden ozone structures from TOMS) effect. At present these features have not sufficiently been explained.

As pointed out by McPeters et al. [1996a] there are uncertainties in the basic measurement in the ozone values obtained by TOMS and in the mathematical procedures used to retrieve them. For global or large-scale purposes the time series of TOMS data (version 7) represents a sound and reliable database, for example, for trend determination [McPeters et al., 1996b]. A comparison based on local measurements shows that the TOMS ozone agrees with average ozone from an ensemble of 30 Northern Hemisphere midlatitude $\left(25^{\circ} \mathrm{N}\right.$ to $\left.55^{\circ} \mathrm{N}\right)$ ground stations to within $\pm 1 \%$ throughout most of a 15-year period [McPeters and Labow, 1996]. Therefore the observed mesoscale variances mentioned above cannot be related to these uncertainties.

The negative correlation of total ozone with tropopause height was known from very early work [Meetham, 1937; Reed, 1950; Dobson, 1963]. Khrgian [1973] interpreted the lower ozone content over the continents in the tropical to subtropical belt as upwelling of air resulting from continental heating. It is well known that the solar heating of high-level topographic surfaces, particularly during summer, leads to a marked warming of the midtroposphere [Zou, 1996]. This effect influences the upper troposphere and could result in a lifting of the tropopause, which in turn reduces the depth of the stratospheric ozone column. For summer, Schubert and Munteanu [1988] found high corresponding correlations in the belt from about $35^{\circ} \mathrm{N}$ to the pole. Recently, Steinbrecht et al. [1998] suggested that ozone changes which occurred over central Europe during the last few years may have been, at least partly, due to the lifting of the tropopause. The existence of land-sea differences in tropopause pressure lifting over the 
continents as compared to the oceans was reported by Crutcher [1969]. Thuburn and Craig [1997] have found, with the help of a global circulation model, that tropopause height is extremely sensitive to the temperature at the Earth's surface and to changes in moisture distribution and related radiative effects. These results suggest that tropopause height may also depend on sea-land distribution.

The first aim of this study is to describe the GHOST effect on a global scale. The second is to evaluate the relative influence of land-sea differences caused by topography and tropopause height variations and the associated changes in total ozone on the GHOST. Total ozone retrieved by TOMS can be affected by ground and cloud reflectivity [McPeters et al., 1996a; McPeters and Labow, 1996], as well as by the UVabsorbing aerosol content [Torres and Bhartia, 1999]. The TOMS total ozone retrieval limitations may also play a role in generating GHOST effects, which will be considered in the present work. A systematic analysis of this effect on a global scale would require accurate information on vertically resolved ozone and aerosols, as well as tropopause height quality-controlled data. This analysis is out of our capabilities. It is reasonable to study these influences in a limited region. The area around the Iberian Peninsula has been selected because above this region, a significant decrease in total ozone is observed during summer. In addition, the climatological conditions of clear sky over the area avoid uncertainties in ozone retrieval caused by cloud cover. Finally, this region is characterized by a wealth of standard meteorological observations. In this study we restrict ourselves to the month of July when the ocean-continent differences are strongest. A period of 11 years (1981-1991) has been used for the study.

The paper is structured as follows: section 2 deals with the data, section 3 describes the GHOST effect in general, and section 4 evaluates and discusses the individual contributions to GHOST above southwestern Europe and northwestern Africa.

\section{Data}

The Nimbus-7 TOMS version 7 ozone data [McPeters et al., 1996a] have been used in gridded form with a resolution of $1^{\circ}$ latitude by $1.25^{\circ}$ longitude. Data missing from this time series are filled in by applying space-time cubic data interpolation. The hypothetical ozone column between topographic height and sea level was estimated from terrain data at a 5-min resolution published by the National Geophysical Data Center (NGDC) [1993].

The 12:00 UTC global fields of the daily tropopause pressure were provided by the National Centers for Environmental Prediction/National Center for Atmospheric Research (NCEP/NCAR) reanalysis at latitude/longitude resolution of $2.5^{\circ}$ by $2.5^{\circ}$. The tropopause pressure was calculated using the thermal definition of the tropopause $[W M O, 1957]$. To validate the tropopause pressures determined by NCEP/NCAR reanalysis for the area of interest, these data were compared with data taken by radiosondes above the Iberian Peninsula: Madrid (19801989), La Coruña (1980-1989), and Palma Majorca (19851988). As the subtropical zone is characterized meridionally by an abrupt change in tropopause pressure, an additional validation was carried out for this area using soundings from Tenerife. It reveals that the NCEP/NCAR tropopause pressure reproduces the bimodal distribution observed by radiosonde data (M. Yela, private communication, 1999). The topography and tropopause data were regridded to match the TOMS ozone grid.

The present study covers a period of 11 years from 1981 to 1991. It would be reasonable to consider seasonal variability of the GHOST effect above the Iberian Peninsula. In an initial study we have learned that above the Northern Hemisphere the GHOST effect is stronger in summer than in winter, peaking in July, when the ocean-land differences are greatest. As the months show similar characteristics albeit with smaller amplitudes, only the results for July will be presented in this study.

\section{Description of GHOST}

Long-term global observations of ozone with the TOMS show a broad variety of scale-dependent stationary structures around the globe (Figure 1). It is well known that large-scale structures in the total ozone are related to large-scale stationary waves [e.g., Wirth, 1993]. Smaller-scale structures, however, have not yet been sufficiently explained. These can be seen by drawing the isolines of the mean total ozone, for example for the month of July, with an increment of 1 (DU) as given in Figure 1. In the Southern Hemisphere during July the TOMS instrument cannot measure beyond $60^{\circ} \mathrm{S}$ due to the absence of sunlight. Figure 1 clearly shows continent outlines although continents themselves have not been drawn in. The appearance of the continents is the result of an abrupt change in the direction of ozone isolines across the coastlines, which arises from a considerable increase in the ozone gradient over these areas. High mountain ranges can be seen for the same reason. In general, the isolines turn toward higher latitudes as soon as these reach a continent.

GHOST is significant at the western coastlines of North and South America, over the Atlantic and Mediterranean coasts of North Africa, and over the western coast of southern Asia. Over the Andes and the Rocky Mountains this effect is very evident. It is still significant above other areas such as the Himalayan plateau, Madagascar, New Zealand, and the Gulf of Guinea. Even over smaller regions such as the Iberian and Arabian Peninsulas and the Alps, the features are clear. The effects are much weaker at the eastern coastlines than at the western edges of the continents. A quantitative evaluation of the GHOST effect over a number of regions is given in Table 1 . The values have been obtained from approximately 4000 grid points. The zonal ozone gradients across the coastlines and high mountains shown in Table 1 range from 1.0 DU to $3.6 \mathrm{DU}$ per $100 \mathrm{~km}$, which is the same order of magnitude observed for the meridional ozone gradient in the Northern Hemisphere.

Figure 2 shows the meridional dependency of mean total ozone values over land and sea between the equator and $55^{\circ} \mathrm{N}$ during July. The zonal mean values were obtained by averaging the corresponding ozone grid values related to land and sea along a parallel of $1^{\circ}$ latitude. This shows that north of $17^{\circ} \mathrm{N}$ the total ozone over the sea is greater in value than over land. The differences disappear at $17^{\circ} \mathrm{N}$ and reverse below that latitude. North of $17^{\circ} \mathrm{N}$ the greatest differences occur within the latitudinal belt between $35^{\circ} \mathrm{N}$ and $40^{\circ} \mathrm{N}$ reaching values of up to $18 \mathrm{DU}$, which is about $6 \%$ of the ozone column. In the equatorial belt the averaged ozone over the sea is much less than that over land. In this region the land/sea 


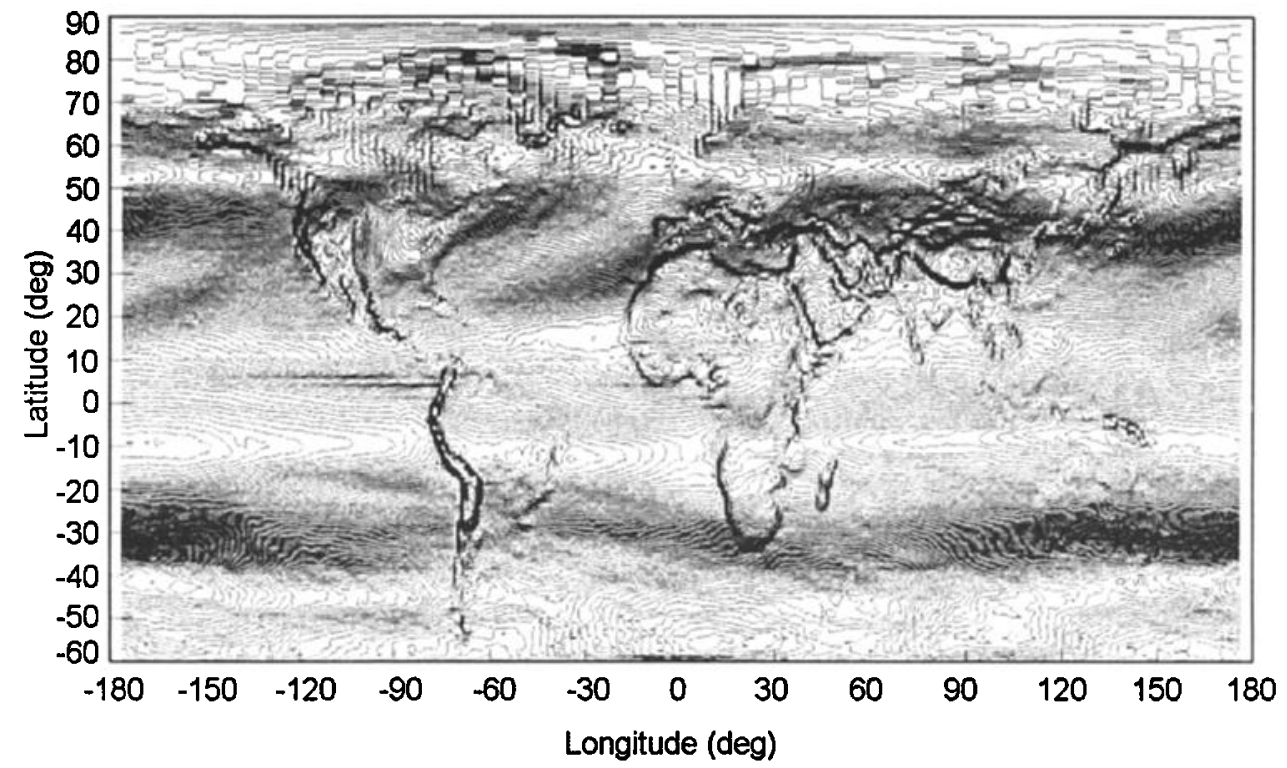

Figure 1. Monthly mean of total ozone from TOMS (version 7) for July 1981-1991. Isolines every 1 DU. Note that continents themselves are not drawn in.

ratio is significantly reduced in comparison with midlatitudes: 0.3-0.4 (equator) versus $0.8-1.6$ (midlatitudes). This feature, together with the fact that ozone variability is dominated by the space-time variability of the strong and deep convection in the Intertropical Convergence Zone (ITCZ), makes averaged land-sea differences in this region questionable.

\section{GHOST Above Southwestern Europe and Northwestern Africa}

In this section, GHOST is studied in detail by investigating a limited region characterized by a significant effect. The chosen region takes in the Iberian Peninsula and ranges from $22^{\circ} \mathrm{N}$ to $50^{\circ} \mathrm{N}$ and $20^{\circ} \mathrm{W}$ to $20^{\circ} \mathrm{E}$. GHOST is hidden to some extent by strong latitudinal gradients and zonal asymmetries in the total ozone resulting from stationary planetary waves

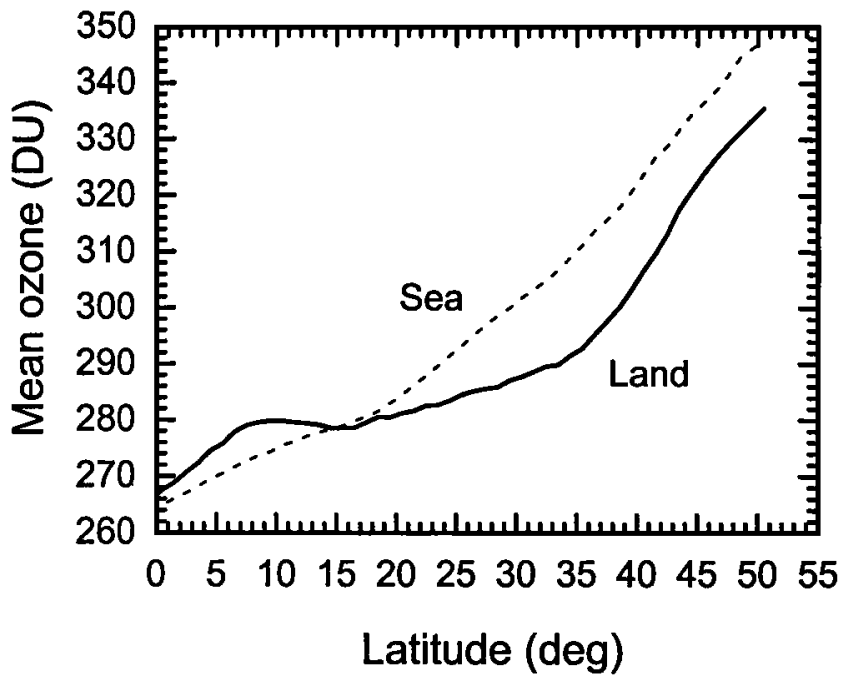

Figure 2. Meridional profile of the mean ozone total column averaged over land and sea over the Northern Hemisphere for July 1981-1991. and blocking high-pressure systems. To extract the GHOST effect from the data, the original data were filtered by removing the zonal gradients, applying a linear regression along each parallel of latitude. In the following these filtered data were used instead of the original total ozone data.

The stationary character of the summer minimum in total ozone above the Iberian Peninsula can be seen in Figure 3. The ozone anomaly appears every year with an almost constant peak-to-peak amplitude. The mean difference between the Atlantic Ocean and the central Iberian Peninsula can be as much as $12 \mathrm{DU}$ and is about $8 \mathrm{DU}$ between the central Iberian Peninsula and the Mediterranean Sea. The regional distribution of the mean ozone anomalies for July is given in Plate 1 (top). It reveals significant cross-coastal gradients around the Mediterranean Sea and at the eastern coasts of the Atlantic Ocean. Lines of constant ozone anomalies follow the shape of the coastlines. This effect is observed even over islands such as Sicily or Sardinia. The most significant negative anomalies in total ozone are observed over the Alps (-11 DU), the Pyrenees ( -7 DU), the Betic cordillera $(-12 \mathrm{DU})$, the Iberic system $(-12 \mathrm{DU})$, the

Table 1. Mean Zonal Sea-Land Differences of Total Ozone $\left(\Delta \mathrm{O}_{3}\right)$ and its Related Zonal Distances $(\Delta x)$ During July Over Various Regions.

\begin{tabular}{ccccc}
\hline $\begin{array}{c}\text { Latitude } \\
\text { (deg) }\end{array}$ & Region & $\begin{array}{c}\text { Peak } \\
\text { Months }\end{array}$ & $\begin{array}{c}\Delta \mathrm{O}_{3} \\
(\mathrm{DU})\end{array}$ & $\begin{array}{c}\Delta x \\
(\mathrm{~km})\end{array}$ \\
\hline $70^{\circ} \mathrm{N}$ & Iceland & May-Aug & 10 & 500 \\
$42^{\circ} \mathrm{N}$ & western North America & Apr-Oct & 14 & 500 \\
$38^{\circ} \mathrm{N}$ & Rocky Mountains & Apr-Oct & 15 & 600 \\
$35^{\circ} \mathrm{N}$ & Himalayan plateau & Jan-Dec & 10 & 1000 \\
$30^{\circ} \mathrm{N}$ & North Africa & Apr-Nov & 12 & 500 \\
$21^{\circ} \mathrm{N}$ & Arabian Peninsula & Jan-Dec & 5 & 500 \\
$20^{\circ} \mathrm{S}$ & Andes & Jan-Dec & 18 & 500 \\
$21^{\circ} \mathrm{S}$ & Madagascar & Jan-Nov & 7 & 500 \\
$28^{\circ} \mathrm{S}$ & South Africa & Jan-Dec & 7 & 600 \\
$38^{\circ} \mathrm{S}$ & western South America & Jan-Dec & 6 & 700 \\
\hline
\end{tabular}




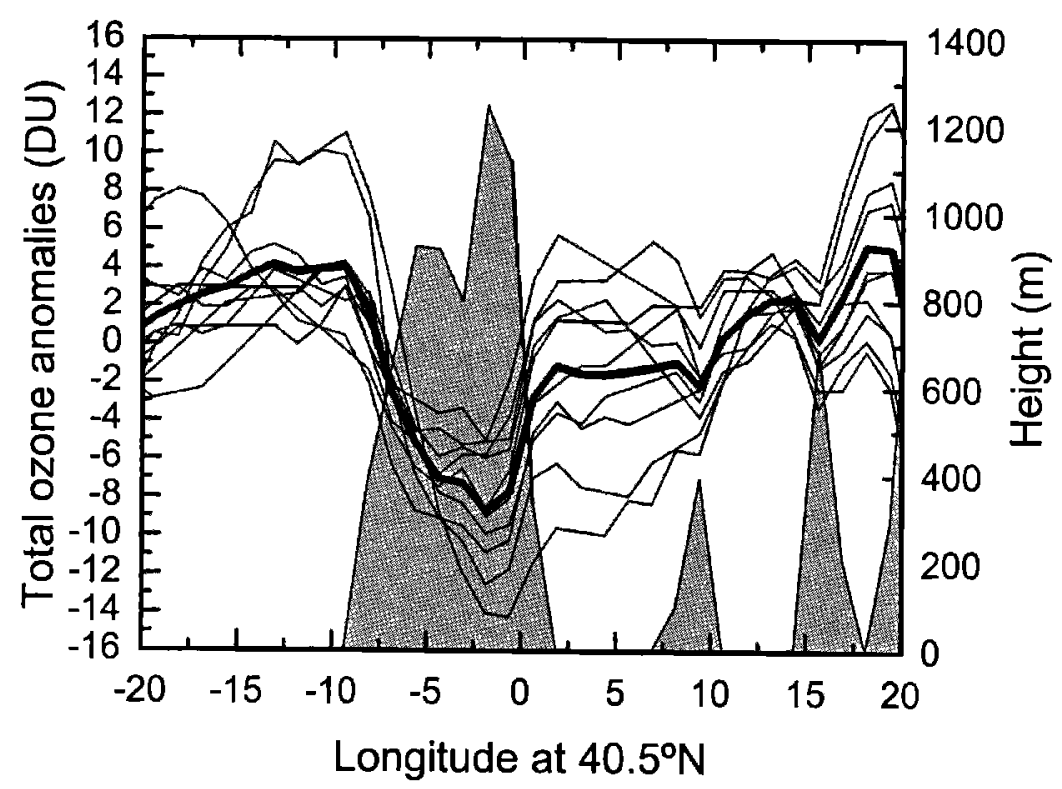

Figure 3. Anomalies from zonally detrended ozone data for all the months of July in the period 1981-1991 along $40.5^{\circ} \mathrm{N}$ (thin lines). The bold line shows the mean value. Shaded areas indicate the topography of the land. The largest area corresponds to the
Iberian Peninsula.

Atlas Mountains (-12 DU), and a minor anomaly (-3 DU) over the Ahaggar massif in south Algeria. The mean standard deviation for the whole area is $3.58 \mathrm{DU}$.

Three possible causes of the observed anomalies in ozone will be discussed in the following subsections to study their effects on GHOST: the influence of topographical height, the effect of ocean-land differences in tropopause height and TOMS ozone retrieval artifacts related to absorbing aerosols.

\subsection{Topographic Contribution}

In Plate 1 (bottom) the topography of the area is shown. We see strong negative anomalies in ozone are related to topography. The contribution of the troposphere to total ozone can be reduced because its depth is reduced as a function of the height of the land below it. To compare ozone columns over the sea with those over land, we have to take into consideration a hypothetical reduction of the tropospheric part of the total ozone by topography. To estimate the contribution to the anomalies, the integrated ozone amount between sea level pressure and terrain pressure ( $c$ in DU) is evaluated by applying the empirical function (adapted from G. Labow, private communication, 1996)

$$
c=F\left[\frac{p_{0}-p_{g}}{\Delta p}\right],
$$

where $p_{0}$ is the mean sea level pressure $(1013 \mathrm{hPa})$ and $p_{\mathrm{g}}$ is the pressure at terrain height. The $\Delta p$ refers to the pressure difference between two reflecting surfaces assumed in the TOMS ozone retrieval algorithm [McPeters et al., 1996a]. The $\Delta p$ is usually set to $608 \mathrm{hPa}$. Function $F$ accounts for the tropospheric contribution depending on the total ozone column and the latitude; it is almost constant for small latitudinal variations and low-ozone seasonal variability. A value of $F$ equal to $22.3 \mathrm{DU}$ has been selected as the best fit to the curve calculated by (1) from observed data measured with electrochemical cell (ECC) ozonesondes released at sea level in southern Spain $\left(37.1^{\circ} \mathrm{N}, 6.4^{\circ} \mathrm{W}\right)$ and Lisbon $\left(38.7^{\circ} \mathrm{N}\right.$, $9.1^{\circ} \mathrm{W}$ ) during July-August. The summer average differences between computed and observed data are less than $4 \%$ within the first $2 \mathrm{~km}$ above mean sea level.

The hypothetical ozone amount between terrain altitude and sea level was added to the monthly mean ozone anomalies at each grid point. The resulting data set contains data that are reduced to the mean sea level. Plate 2 shows the ozone anomaly for July where the topographic correction has been included. Apparently, small anomaly features as observed above Sardinia, Sicily, and the Balearic Islands have vanished, whereas significant anomalies remain above the Alps, the Iberian Peninsula, and North Africa. The greatest anomaly reduction occurred over high mountainous terrain, such as the Alps, the Iberian Peninsula, and the Atlas Mountains. After applying the topographic correction these mountain ranges can hardly be recognized in the anomaly field. Above the Iberian Peninsula the negative anomaly reduces from -9 DU to -5 DU. A similar reduction of the anomalies can be seen over the Atlas Mountains. The averaged amount of the topographic correction for the entire Iberian Peninsula is about 2 DU. When applying this correction, the standard deviation of the entire area is reduced by $26 \%$ to $2.67 \mathrm{DU}$.

\subsection{Tropopause Height Contribution}

It is well known that a lifting of the tropopause might reduce the total ozone column because at tropopause level tropospheric air with low ozone concentrations replaces stratospheric air with high ozone values resulting in a total ozone decrease [Meetham, 1937; Reed, 1950]. Correspondingly, a descending tropopause increases the total ozone. Published work gives a broad variety of regression coefficients describing the change in the amount of ozone versus the change in tropopause height. Meetham [1973] reported $10 \mathrm{DU} / \mathrm{km}$, and Reed [1950] obtained $22 \mathrm{DU} / \mathrm{km}$. For 


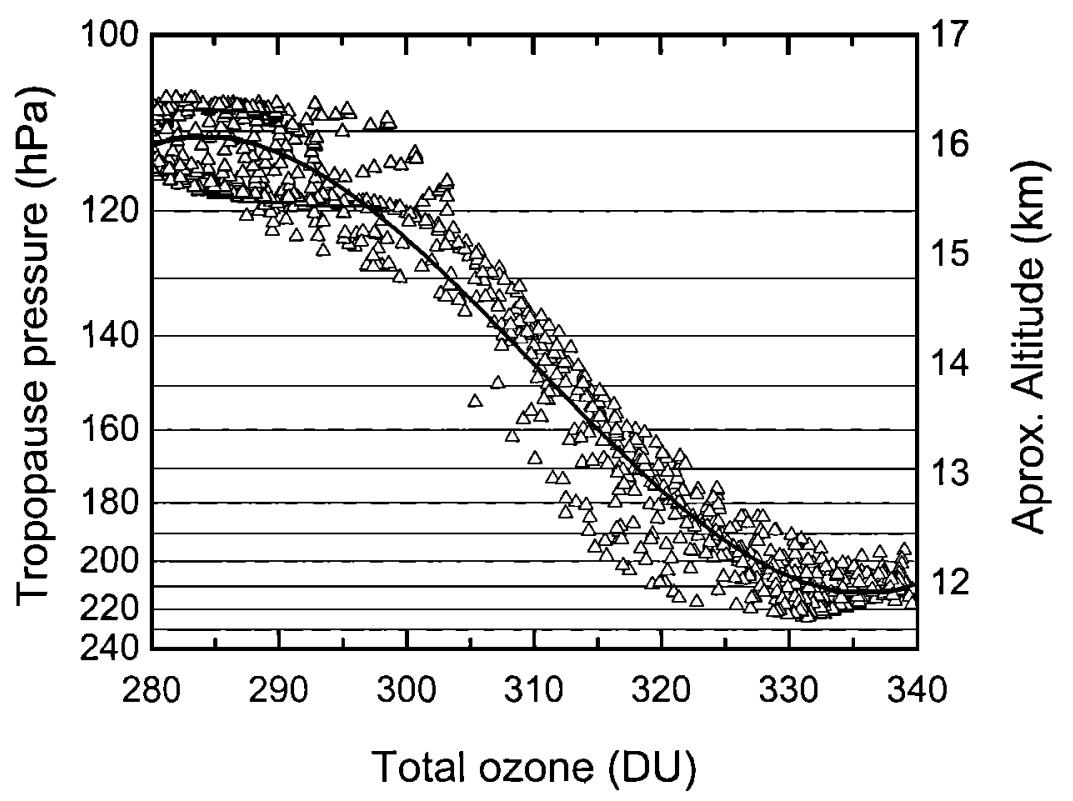

Figure 4. Mean total ozone versus mean tropopause pressure, the triangles indicate mean grid point values within the area $20^{\circ} \mathrm{W}$ to $20^{\circ} \mathrm{E}$ and $22^{\circ} \mathrm{N}$ to $50^{\circ} \mathrm{N}$. Each value is averaged over days for all the months of July in the period 1981-1991. The solid curve indicates a fourth-order polynomial fit to the data sample.

Central Europe, Hoinka et al. [1996] calculated a range of 13 to $16 \mathrm{DU} / \mathrm{km}$. It is the generally understood that the regression coefficient depends strongly on the geographical region, season, and synoptic weather system.

Therefore a regression coefficient between tropopause pressure and total ozone is determined for the region of interest, using data from each July between 1981 and 1991. For all the grid points within the area $20^{\circ} \mathrm{W}$ to $20^{\circ} \mathrm{E}$ and $22^{\circ} \mathrm{N}$ and $50^{\circ} \mathrm{N}$, mean values are calculated by averaging the days for all the months of July of the chosen period. The results are shown in Figure 4. The data sample given is approximated by a fourth-order polynomial fit, which reproduces the sample sufficiently. It shows a quasi-linear dependency between 300 and $330 \mathrm{DU}$ of $8.6 \mathrm{DU} / \mathrm{km}$. Above and below these limits it deviates from linearity which results from zonal asymmetries in the tropopause field not reflected in the total ozone field. The branch at the lowermost ozone range is representative of the tropics where the correlation of total ozone with tropopause altitudes decreases significantly, as was stated by Schubert and Munteanu [1988]. The subtropical jet marks an abrupt change between tropical and midlatitude tropopause. In the area of interest the position of the jet matches the ozone isoline of 300 DU during July [Yela et al., 1998]. Before applying the residual technique used in the topography correction, the vertical coordinate must be linearized. We have used a third-order polynomial function from the Air Force Geophysical Laboratory (AFGL) climatology at summer midlatitudes to carry out the pressure-to-height conversion $\left(r^{2}=0.9999\right)$.

The original data were filtered, as was the ozone data, by removing the zonal gradients and applying a linear regression along each parallel of latitude. The result is shown in Figure 5 (top). At $40^{\circ} \mathrm{N}$ there is a zonal change in tropopause height of more than $1.2 \mathrm{~km}$ between the western Mediterranean Sea and the Atlantic Ocean. This zonal asymmetry is due to the wavy pattern of the tropopause isohypse associated with the summer subtropical jet [Cuevas, 1995].
The total ozone anomaly, which is calculated from the tropopause height anomaly by using the fourth-order fitted curve is given in Figure 5 (bottom). The anomaly field exhibits a minimum to the east and a maximum to the west of the peninsula. The zonal asymmetry appears differently in the topographically corrected anomaly field (Plate 2). Another discrepancy is that the minimum observed over the Atlas Mountains appears only in the case of topographically corrected ozone anomalies. Because of these differences between the anomaly fields, the corresponding correlation coefficient is only 0.61 . Nevertheless, to show the influence caused by topography and tropopause height, both anomaly fields were subtracted from the original anomaly field given in Plate 1 (top). The result is shown in Plate 3. As expected from the results given in Plate 2 and Figure 5 (both, top), there are minima over the Iberian Peninsula, North Africa, and the western Mediterranean Sea. The anomalies associated with the high ranges, such as the Alps, the Pyrenees, the Betic-Iberic system, and the Atlas Mountains have completely disappeared. This fact suggests that these anomalies are the result of the topography and of the anomalies in the height of the tropopause.

The application of both corrections reveals that over the Iberian Peninsula the remaining anomaly is now located nearer the center of the peninsula, whereas the minimum was located over southeastern Spain in the original data field. The Mediterranean coastlines of southeastern Spain and North Africa are now visible, clearly characterized by a crosscoastal ozone difference. A similar value is obtained after the application of the topographic correction, but the standard deviation of the data field given in Plate 3 has been reduced to 2.37 DU. The change in tropopause height and the related change in total ozone does not contribute to the occurrence of the summer minimum in total ozone over the Iberian Peninsula. However, it does play a role by reducing the zonal asymmetries from the topographically corrected field by $8 \%$. 

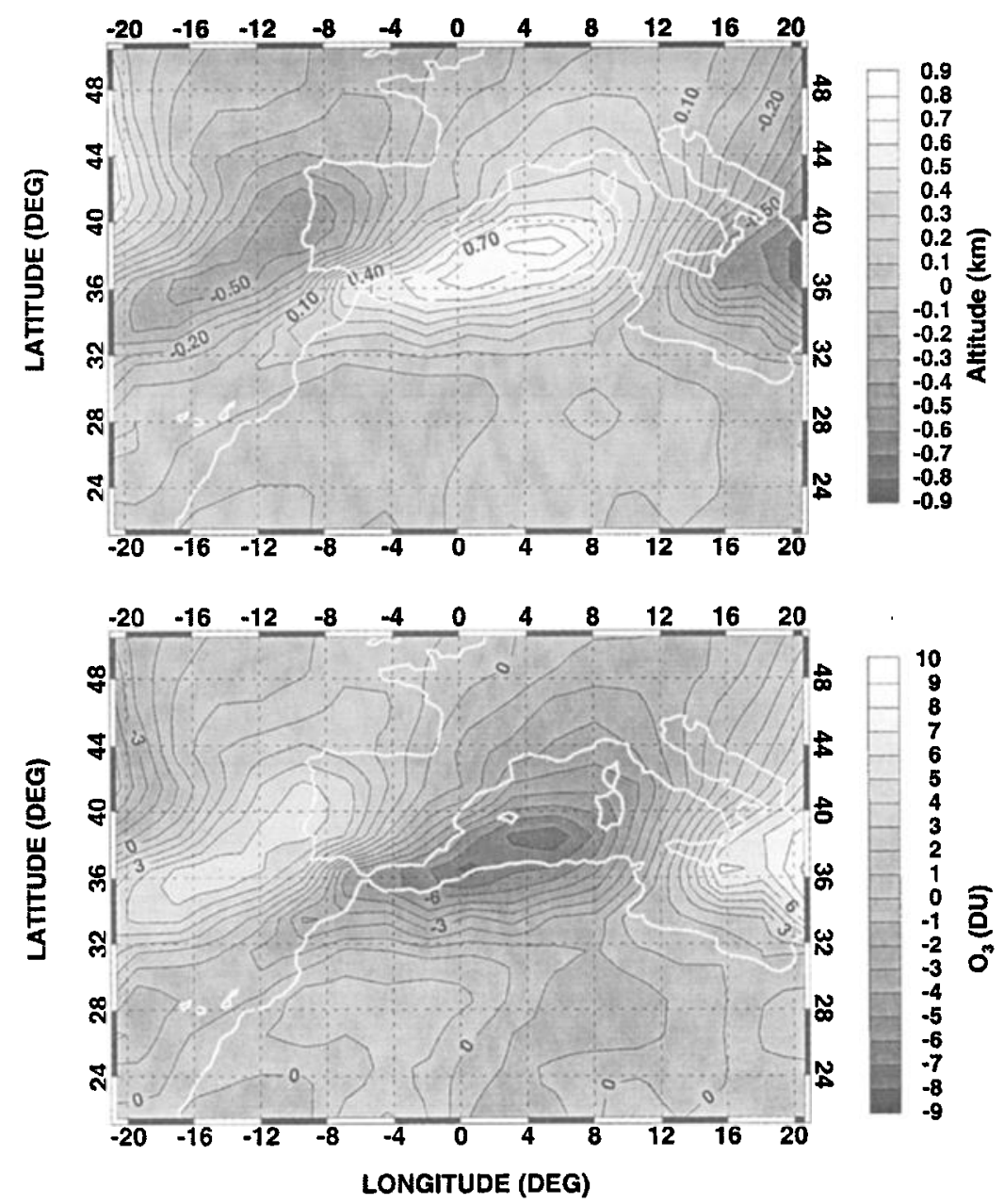

Figure 5. (top) Anomalies from zonally detrended tropopause height data for all the months of July in the period 1981-1991. (bottom) Corresponding ozone anomalies as calculated by the fourth-order polynomial regression function (see text).

\subsection{TOMS Ozone Retrieval Artifact: Reflectivity and Aerosols}

After the application of the topographic and tropopause height correction to the original data, two areas within the selected region show negative anomalies in total ozone of up to $5 \mathrm{DU}$. At least one additional third mechanism is needed to explain the remaining ozone anomalies in these areas. Both the Iberian Peninsula and North Africa are characterized by strong surface heating during summer generating large thermally driven systems during the day. This heated lowpressure system is a frequent feature over both regions [Portela and Castro, 1996]. The peak month for this is July. In the following we will show that the remaining anomalies can be related to the interference of aerosols in the TOMS ozone retrieval.

The retrieval of ozone data from TOMS treats reflectivity as the linear combination of two contributions: an assumed surface reflectivity and an assumed cloud reflectivity [McPeters et al., 1996a]. When reflectivity is less than $8 \%$, it is considered the reflectivity of the surface. For UV wavelengths the surface reflectivity of land and water are quite similar [Paltridge and Platt, 1976], except for snow cover. Thompson et al. [1993] reported an overestimation of ozone content over persistent marine stratocumulus by assuming the cloud height to be a simple function of the latitude in TOMS version 6. Version 7 of the retrieval uses improved ISCCP (International Satellite Cloud Climatology Project) climatology, higher-resolution terrain height data, a more accurate model for partially clouded pixels, improved radiative transfer calculations, and triplets of wavelengths. The latter is used instead of pairs to remove most of the effects of wavelength-dependent reflectivity. A comparison of TOMS and 30 Northern Hemisphere midlatitude $\left(25^{\circ} \mathrm{N}\right.$ to $55^{\circ} \mathrm{N}$ ) ground-based Dobson data [McPeters and Labow, 1996] shows that for clear skies with reflectivity of less than $10 \%$ the differences in total ozone taken by both instruments are close to zero. Clear-sky conditions occur frequently in July over the Iberian Peninsula.

Recently, Torres and Bhartia [1999] have pointed out that silicate UV-absorbing aerosols induce an underestimation in the TOMS column which is dependent not only on the aerosol optical depth (AOD) but also on the altitude of the aerosol layer. Poor soils covering extensive areas of eastern, southern and central Spain account for high crustal emissions [Artiñano et al., 2001], mainly formed by aluminum silicates, quartz, and carbonates (X. Querol, private communication, 2000). According to Querol et al. [1998], even around a large power station the crustal fraction predominates (around $35 \%$ of the bulk particulate load) in the suspended particles. This confirms the importance of silicates in the background levels. 

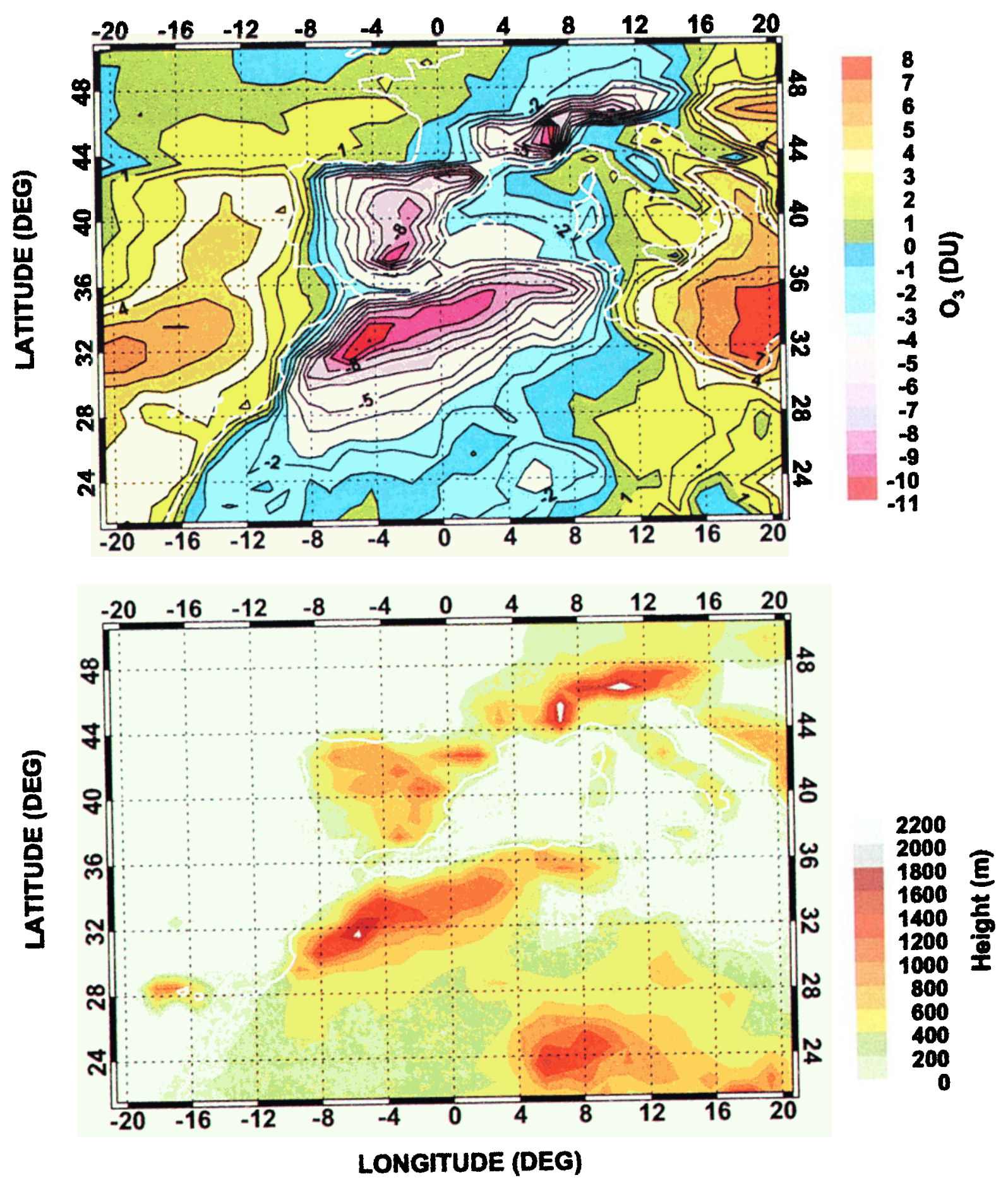

Plate 1. Anomalies from zonally detrended ozone data for all the months of July in the period 1981-1991 (top), topography (bottom). 


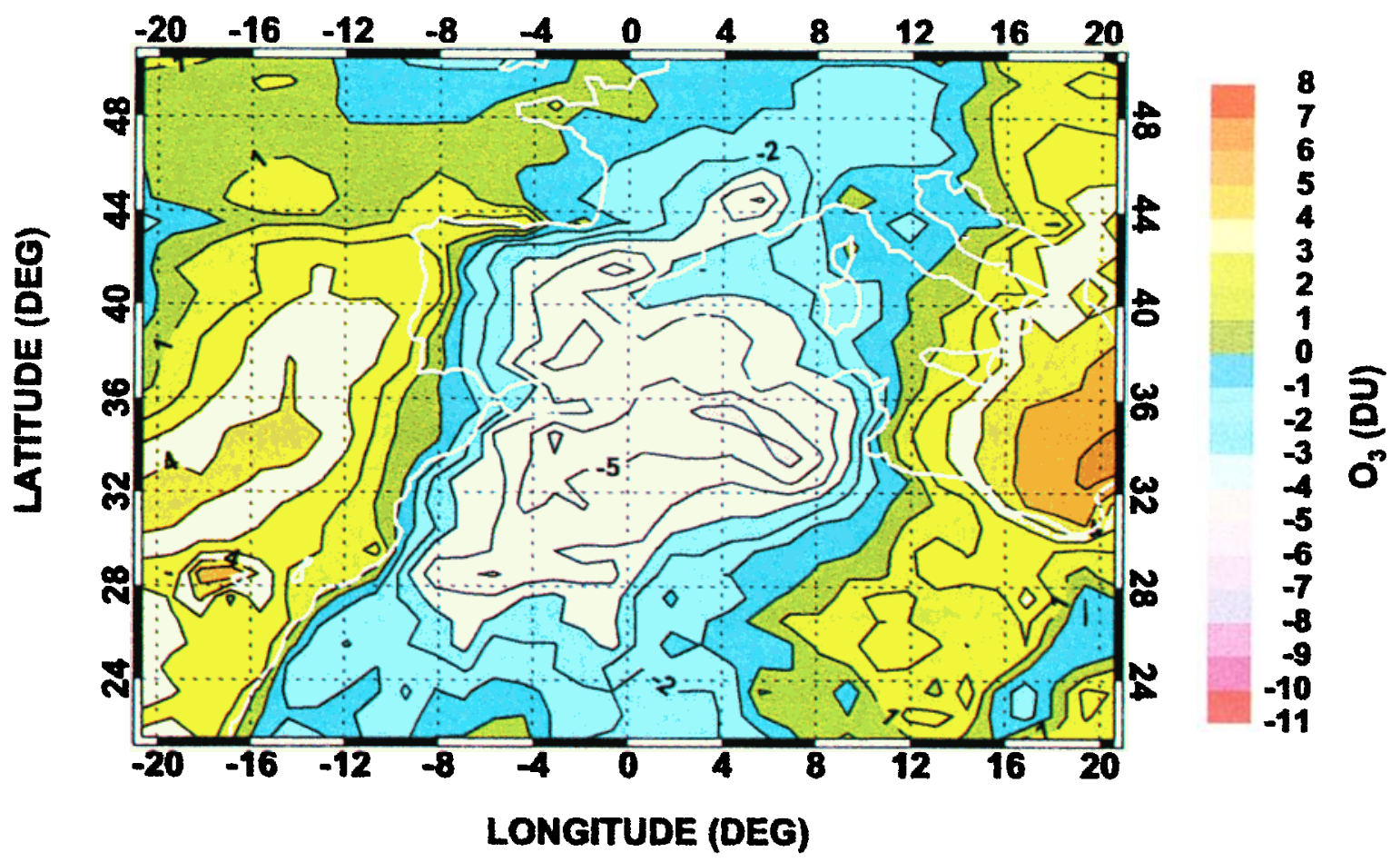

Plate 2. As in Plate 1 (top) but including the "topographical correction." For definition, see text.

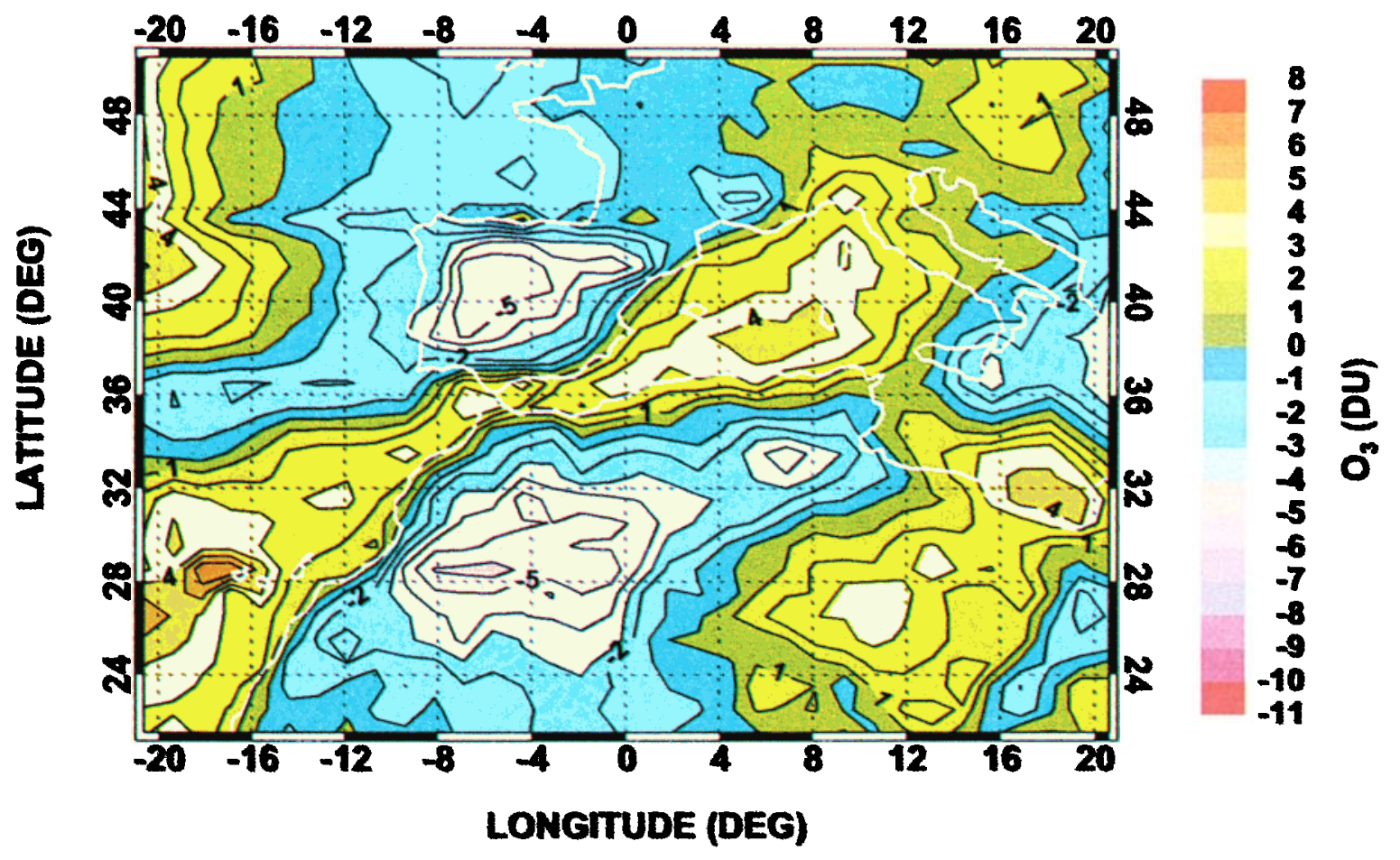

Plate 3. Anomalies in total ozone after applying the topographical correction and a "tropopause height correction." For definition, see text. 
In summer the surface of the Iberian Peninsula, under the influence of a high-pressure system, is heated considerably during the day and large thermally driven systems develop. The peak month for this is July. Through these mechanisms, upwelling and vertical mixing of soil-related aerosols occur in the lower troposphere, from the ground up to $2.5 \mathrm{~km}$ [Portela and Castro, 1996]. This height represents the typical upper limit of the boundary layer over the Iberian Peninsula in summertime.

In summer the mean AOD is 0.3 at $550 \mathrm{~nm}$ over the Iberian Plateau [Cachorro et al., 2000a], while at $380 \mathrm{~nm}$ it ranges from 0.5 to 0.6 [Cachorro et al., 2000b]. Over the sea, the AOD is mainly influenced by natural nonabsorbing marine aerosols. In summer the AOD is 0.1 at $550 \mathrm{~nm}$ over the Atlantic Ocean west of the Iberian Peninsula and 0.2-0.3 over the Mediterranean Sea [Husar et al., 1997]. The AOD increases close to the coast, indicating higher loading over land than over ocean. Boundary layer measurements over the North Atlantic Ocean during summer show an AOD of 0.04 , whereas it is 0.2 above the western Mediterranean [Moulin et al., 1997].

Torres and Bhartia [1999] calculated the expected underestimation in total ozone retrieved by TOMS as a function of the $A O D$, and the height of the top of the aerosol layer, at $380 \mathrm{~nm}$. According to them, for an AOD of 0.5 of UV-absorbing aerosols and an aerosol layer of $2 \mathrm{~km}$ in depth, the ozone is underestimated by about $2.5 \%$. This represents about 8 DU over the Iberian Peninsula in summer, which is consistent with the negative anomaly observed after applying the topography correction to the data. Therefore the summer UV-absorbing acrosol layer represents the most probable and only identified cause of the unexplained minimum of total ozone measured above the Iberian Peninsula.

In July when the maximum pickup of Saharan dust occurs, a maximum in wind velocity is observed at $850 \mathrm{hPa}$ above the northwestern Sahara south of the Atlas Mountains [Newell and Kidson, 1979]. This dust is transported toward southern Algeria, Morocco, and the former Spanish Sahara [Kalu, 1979] where it forms a hazy dust layer confined to the lowest $3 \mathrm{~km}$ [Prospero and Carlson, 1972]. Unfortunately, there is no AOD data available for this region, but it is suggestive that here (see Plate 3), as with the Iberian Peninsula, the UVabsorbing aerosol may also result in a negative ozone anomaly.

A second case analysis was performed for another clearsky area, the Arabian Peninsula (not shown in this paper), with the same results concerning the topographic and tropopause height corrections. The summer conditions above the Arabian Peninsula are comparable to those observed above the Iberian Peninsula, and it is therefore reasonable to apply the presented results to this region and to other regions with similar characteristics.

The effect of UV-absorbing aerosols vanishes over high mountains due to negligible aerosol load at higher altitudes. This is in accordance with the fact that the negative ozone anomalies observed over these regions disappear after the application of the topographic and tropopause height correction.

\section{Summary}

Time-averaged ozone fields from TOMS show significant mesoscale gradients across coastlines and across orographic slopes. These gradients in ozone are referred to as the GHOST (global hidden ozone structures from TOMS) effect. In the present study the global characteristics of this effect have been described for all the months of July from 1981 to 1991 . It is easily distinguishable in midlatitudes and subtropical regions within a latitudinal belt between $40^{\circ} \mathrm{S}$ and $50^{\circ} \mathrm{N}$. The greatest land-sea differences in mean total ozone of up to 18 DU are observed between $35^{\circ} \mathrm{N}$ and $40^{\circ} \mathrm{N}$ during Northern Hemispheric summer.

The influence of topography, tropopause height variations, and tropospheric absorbing aerosol on the regional structure of ozone anomalies was evaluated for southwestern Europe and northwestern Africa. Significant anomalies in total ozone were observed over the Alps, the Iberian Peninsula, North Africa, and the Atlas Mountains. The averaged anomaly amplitude between the central Iberian Peninsula and the Atlantic Ocean reaches about $12 \mathrm{DU}$ and is about $8 \mathrm{DU}$ between the Iberian Peninsula and the Mediterranean Sea.

The original TOMS data were topographically corrected by estimating the residual ozone mass between terrain height and sea level. The most marked anomaly diminution occurred over high mountainous terrain, such as the Alps and the Atlas Mountains. After applying the topographic correction, both mountain ranges can hardly be recognized in the anomaly field. This correction reduces the regionally averaged standard deviation of ozone to $74 \%$ of its value obtained from the original TOMS data.

A linear regression coefficient between changes in the tropopause height and related changes in the total ozone were calculated for the selected region. The resulting regression coefficient of $8.6 \mathrm{DU} / \mathrm{km}$ was used to estimate the change in total ozone related to a corresponding change in tropopause height. After correcting the ozone data both topographically and for tropopause height, it shows minima in total ozone over the Iberian Peninsula, North Africa, and the western Mediterranean Sea. The ozone data, when corrected over both land areas, show negative anomalies in total ozone of up to 5 DU. The anomalies over the Alps, the Pyrenees, the BeticIberic system and the Atlas Mountains have disappeared completely, which suggests that these anomalies are the result of the 'topographic' and 'tropopause height' anomaly. The application of both corrections also reveals that over the Iberian Peninsula the remaining anomaly is now located nearer the center of the peninsula, whereas in the original data field it was found over southeastern Spain. The Mediterranean coastlines of Spain and of North Africa now appear clearly characterized by a cross-coastal ozone difference. The tropopause height correction reduces the regional standard deviation by an additional $8 \%$, with a remaining $66 \%$ of its original value.

Recent observations of aerosol optical depth as well as distribution and composition of the aerosols over the Iberian Peninsula and North Africa suggest that the lower ozone over these areas may result from an underestimation of total ozone in the TOMS retrieval procedure due to the absorbent character of the boundary layer aerosol over land and the nonabsorbent layer over the sea. Unfortunately, at present we cannot directly determine the magnitude of this deficit because it would require an accurate nonpolluted groundbased spectrophotometric data set, which is unavailable for the Iberian Peninsula. However, an approximate value for this deficit was estimated, following Torres and Bhartia [1999], as a function both of the aerosol optical depth and the top 
height of the aerosol layer. Over the Iberian Peninsula in summer the magnitude of total ozone is $2.5 \%$ (8 DU) lower than over the surrounding seas. This value is consistent with the negative anomaly observed there after applying the topographic and tropopause height correction to the original TOMS data. These calculations suggest that the summer absorbing aerosol layer may play a leading role in generating the minimum in total ozone measured over the Iberian Peninsula.

Both the Iberian Peninsula and North Africa, are characterized by strong surface heating during summer generating large thermally driven systems during the day. Since the summer conditions over the Arabian Peninsula and North Africa are comparable to those observed over the Iberian Peninsula, it is reasonable to apply the results presented here both to these regions and to other regions with similar surface and tropospheric characteristics.

A complete explanation of the GHOST effect on a global scale requires global sets of information on atmospheric parameters and has not been attempted. While global topography and tropopause height correction can be performed, and will be the subject of future work, the analysis of mesoscale structures should be carried out case by case. At present the origin of these features remains unexplored.

Acknowledgments. The authors wish to express their appreciation to Walter Komhyr (at that time at NOAA/CMDL) for encouraging us to publish these results. The authors also would like to thank the TOMS team at NASA/GSFC for providing the TOMS data, the Climate Diagnostics Center (NOAA) for the NCAR/NCEP reanalysis of tropopause data in gridded form, the National Geophysical Data Center (NOAA) for making the Global Relief data available, Diamantino V. Henriques (Instituto de Meteorologia, Portugal), and Juan M. Cisneros (Instituto Nacional de Meteorologia, Spain) for kindly supplying the Dobson, Brewer, and sounding data.

\section{References}

Artíñano, B., X. Querol, P. Salvador, S. Rodríguez, D. G. Alonso, and A. Alastuey, Assessment of airborne particulate levels in Spain in relation to the New Eu-Directive, Atmos. Environ., 35, supplement No. 1, 543-553, 2001.

Bojkov, L. R. D., C. L. Mateer, and H. L. Hanson, Comparison of ground-based and total ozone mapping spectrophotometer measurements used in assessing the performance of the Global Ozone Observing System, J. Geophys. Res., 93, 9525-9533, 1988.

Cachorro, V. E., R. Vergaz, M. J. Martin, A. M. de Frutos, J. M. Vilaplana, and B. de la Morena, Measurements and estimation of the aerosol optical depth in the UV spectral range, Appl. Opt., in press, 2000a.

Cachorro, V. E., P. Durán, R. Vergaz, and A. M. de Frutos, Measurements of the atmospheric turbidity of the north-center continental area in Spain: Spectral aerosol optical depth and Angstrom turbidity parameters, J. Aerosol Sci., 31, 687-702, $2000 \mathrm{~b}$.

Crutcher, H. L., Temperature and humidity in the troposphere, in Climate of the Free Atmosphere, pp. 45-83, Elsevier, New York, 1969.

Cuevas, E., Estudio del comportamiento del Ozono Troposférico en el Observatorio de Izaña (Tenerife) y su relación con la dinámica atmosférica, (in Spanish), Ph.D.thesis, 251 pp., Univ. Complutense de Madrid, Spain, 1995 (Available by e-mail from ecuevas@inm.es.)

Danilov, A. D., E. S. Kazimirovsky, B. A. de la Morena, and M. Gil, The variations of ozone total content over mountains, (in Russian), Geomagn. Aeron., 35, 108-115, 1995.

Dobson, G. M. B., Exploring the Atmosphere, 188 pp., Clarendon, Oxford, England, 1963.

Fishman, J., C. E. Watson, J. C. Larsen, and J. A. Logan, Distribution of tropospheric ozone determination from satellite data, $J$. Geophys. Res., 95, 3599-3617, 1990.

Harris, N. R. P., et al., Trends in stratospheric and free tropospheric ozone, J. Geophys. Res., 102, 1571-1590, 1997.

Hoinka, K. P., H. Claude, and U. Köhler, On the correlation between tropopause height and total ozone above Central Europe, Geophys. Res. Lett., 23, 1753-1756, 1996.

Husar, R. B., J. M. Prospero, and L. L. Stowe, Characterization of tropospheric aerosols over the oceans with the NOAA advanced very high resolution radiometer optical thickness operational product, J. Geophys. Res, 102, 16,889-16,909, 1997.

Kalu, A. E., The African dust plume: Its characteristics and propagation across west Africa in winter, in Saharan Dust, Scope Rep. 14, 297 pp., edited by C. Morales, John Wiley, New York,
1979 .

Kazimirovsky, E. S., and A. D. Danilov, The total ozone content and orography, Adv. Space Res., 20(6), 1265-1268, 1997.

Khrgian, A. K., G. I. Kuznetsov, and A. V. Kondratyeva, in Atmospheric Ozone, 90 pp., Isr. Program for Sci. Transl.,
Jerusalem, Israel, 1967.

Kulkami, R. N., R. D. Angregi, and K. R. Ramanathan, Comparison of ozone amounts measured at Delhi $\left(28.5^{\circ} \mathrm{N}\right)$, Srinagar $\left(34^{\circ} \mathrm{N}\right)$, and Tateno $\left(36^{\circ} \mathrm{N}\right)$ in 1957-58, Pap. Meteorol. Geophys., 10, 85-
92,1960 .

McPeters, R. D., and G. J. Labow, An assessment of the accuracy of 14.5 years of Nimbus 7 TOMS Version 7 ozone data by comparison with the Dobson Network, Geophys. Res. Lett., 23,
3695-3698, 1996.

McPeters, R. D., et al,, Nimbus-7 Total Ozone Mapping Spectrometer (TOMS) data products user's guide, NASA Ref. Publ. 1384, 97 pp., Nat. Aeronaut. and Space Admin., Washington, D.
C., 1996a.

McPeters, R. D., S. M. Hollandsworth, L. E. Flynn, J. R. Herman, and C. J. Seftor, Long-term ozone trends derived from 16-years combined Nimbus-7/Meteor-3 TOMS version 7 record, Geophys.
Res. Lett., 23, 3699-3702, 1996b.

Meetham, A. R., The correlation of the amount of ozone with other characteristics of the atmosphere, Q.J.R. Meteorol. Soc., 63, 289307, 1937.

Moulin, C., F. Guillard, F. Dulac, and C. E. Lambert, Long-term daily monitoring of Saharan dust load over ocean using Meteosat ISCCP-B2 data, 1, Methodology and preliminary results for 19831994 in the Mediterranean, J. Geophys. Res., 102, 16,947-16,958, 1997.

Newell, R. E., and J. W. Kidson, The tropospheric circulation over Africa and its relation to the global tropospheric circulation, in Saharan Dust, Scope Rep. 14, 297 pp., edited by C. Morales, John Wiley, New York, 1979.

National Geophysical Data Center (NGDC), ETOPO5 5-minute gridded elevations/bathymetry for the world, Global Relief Data [CD-ROM], Boulder, Colo., 1993.

Paltridge, G. W., and C. M. R. Platt, Radiative processes in meteorology and climatology, Elsevier Sci., New York, 1976.

Portela, A., and M. Castro, Summer thermal lows in the Iberian Peninsula: A three dimensional simulation, Q. R. Meteorol. Soc.,
122(529), 1-22, 1996 .

Prospero, J. M., and T. N. Carlson, Vertical and areal distribution of Saharan dust over the western equatorial North Atlantic Ocean, $J$. Geophys. Res., 77, 5255-5265, 1972.

Querol, X., A. Alastuey, J. A. Puicercus, E. Mantilla, C. R. Ruiz, A. Lopez-Soler, F. Plana, and R. Juan, Seasonal evolution of suspended particles around a large coal-fired power station: Chemical characterization, Atmos. Environ., 32(4), 719-731, 1998.

Reed, R. J., The role of the vertical motions in ozone-weather relationship, J. Meteorol., 7, 263-267, 1950.

Schubert, S. D., and M. J. Munteanu, An analysis of tropopause pressure and total ozone correlations, Mon. Weather Rev., 116,
$569-582,1988$.

Starovatov, A. A., and A. L. Zheleznyakova, A minimum of stratospheric ozone over Pamir, Ann. Geophys., 13, 1343-1347,
1995 .

Steinbrecht, W., H. Claude, U. Köhler, and K. P. Hoinka, Correlations between tropopause height and total ozone: Implications for long-term changes, J. Geophys. Res., J03, 
Stolarski, R. S. P., R. Bojkov, L. Bishop, C. Zerefos, J. Staehlin, and J. Zawodny, Measured trends in stratospheric ozone, Science, 256, 342-349, 1992.

Thompson, A .M., D. P. McNamara, K. E. Pickering, and R. D. McPeters, Effect of marine stratocumulus on TOMS ozone, $J$. Geophys. Res., 98, 23,051-23,057, 1993.

Thubum, J., and G. C. Craig, GCM Tests of theories for the height of the tropopause, J. Atmos. Sci., 54, 869-882, 1997.

Torres, O., and P. K. Bhartia, Impact of tropospheric aerosol absorption on ozone retrieval from backscattered ultraviolet measurements, J. Geophys. Res., 104, 21,569-21,577, 1999.

Wirth, V., Quasi-Stationary planetary waves in total ozone and their correlation with lower stratospheric temperature, J. Geophys. Res., 98, 8873-8882, 1993.

Wurlù Mútétóólógical Organization (WMO), Definition of the tropopause, WMO Bull. 6, 136 pp., Geneva, Switzerland, 1957.

Yela, M., M. Gil, M. Navarro, S. Rodriguez, E. Cuevas, and C. Romero, Meridional transport in the subtropics during winter as seen by $\mathrm{NO}_{2}$ column record, Air Poll. Rep. 66, EUR $18032 E N$, edited by N. R. P. Harris, I. Kilbane-Dawe, and G. T. Amanatidis, pp. 88-91, European Commission, Schliersee, Germany, 1998.

Zou, H., Seasonal variations and trends of TOMS ozone over Tibet, Geophys. Res. Lett, 23, 1029-1032, 1996.

E. Cuevas, J. Rodríguez, Observatorio Atmosférico de Izaña, Instituto Nacional de Meteorologia, La Marina 20, 38071 Santa Cruz de Tenerife, Spain. (ecuevas@inm.es; boriel@arrakis.es)

M. Gil, M. Navarro, LATMOS-Departamento de Observación de la Tierra, Teledetección y Atmósfera, Instituto Nacional de Técnica Aeroespacial, Ctra. de Ajalvir km 4, Torrejón de Ardoz, 28850 Madrid, Spain. (gilm@inta.es; navarrocm@inta.es)

K. P. Hoinka, Institut für Physik der Atmosphäre, Deutsches Zentrum für Luft- und Raumfahrt, Oberpfaffenhofen, D-82234 Weßling, Germany. (Klaus.Hoinka@dlr.de)

(Received September 22, 2000; revised March 19, 2001; accepted May 23, 2001.) 